\begin{tabular}{|c|c|}
\hline Dostępne online www.journals.wco.pl/los & Letters in Oncology Science \\
\hline Zeszyty Naukowe WCO, Letters in Oncology Science 2016;13(4):83-91 & ISSN 2543-6724 \\
\hline Praca poglądowa/Review paper & $\begin{array}{l}\text { ZESZYTY NAUKOWE WIELKOPOLSKIEGO } \\
\text { CENTRUM ONKOLOGII }\end{array}$ \\
\hline
\end{tabular}

\title{
Ocena najnowszych trendów w diagnozowaniu, leczeniu nowotworów złośliwych w lokalizacji dolnego odcinka przewodu pokarmowego na podstawie konferencji ASTRO’s 56th Annual Meeting
}

\section{Assessment of the latest trends in diagnosis and treatment of lower digestive tract cancers based on ASTRO's 56th Annual Meeting}

Piotr Janiga ${ }^{1}$

${ }^{1}$ Zakład Radioterapii I

\section{Streszczenie}

Na konferencji ASTRO 56th Meeting w części poświęconej nowotworom dolnego odcinka przewodu pokarmowego prezentowane były najnowsze doniesienia dotyczące raka odbytnicy i odbytu. Praktycznie brak nowych badań ściśle związanych z rakiem okrężnicy, zarówno w wystąpieniach ustnych jak i plakatowych.

Standardy leczenia raka odbytnicy nie uległy zmianie, jednak zarysowują się trendy: deeskalacja leczenia chirurgicznego oraz propozycje modyfikacji - skracania czasu trwania leczenia neoadjuwantowego.

\begin{abstract}
Abstrakt
At the ASTRO 56th Meeting, in the part related to lower digestive tract cancers, the latest reports were presented on anal and rectal cancers. Basically, no mention was made, whether orally or on posters, of colon cancer.

Treatment standards for rectal cancer have not been changed, however, some new trends have developed: de-escalation of surgery and modification proposals - shortening of neoadjuvant treatment.
\end{abstract}

Stowa kluczowe: rak odbytnicy, rak odbytu, radioterapia, onkologia, badania kliniczne

Keywords: rectal cancer, anal cancer, radiotherapy, oncology, clinical trials

Piotr Janiga

Zakład Radioterapii I

Wielkopolskie Centrum Onkologii, ul. Garbary 15, 61-866 Poznań, Polska

e-mail: piotr.janiga@wco.pl 
Minimalizacji leczenia dotyczy badanie III fazy GRECCAR II, przeprowadzone we Francji [1]. Stosowano w nim trójstopniową procedurę: poddawano chorych indukcyjnej radiochemioterapii, po której dokonywano oceny odpowiedzi. Pacjentów z dobrą odpowiedzią przydzielano losowo do grupy leczonej klasycznie całkowitym wycięciem mezorektum (TME) lub do grupy leczonej poprzez miejscową resekcję. W tej drugiej grupie, jeśli stwierdzono cechę pTo-1 oraz niezajęte marginesy - kończono leczenie, w przeciwnym wypadku dokonywano konwersji operacji do TME. Takie podejście było dość ryzykowne, albowiem badacze ryzykowali brak akceptacji pacjentów dla proponowanego schematu leczenia a w konsekwencji słaby nabór do badania.

Istotna była selekcja pacjentów:

\section{GRECCAR 2 Design}

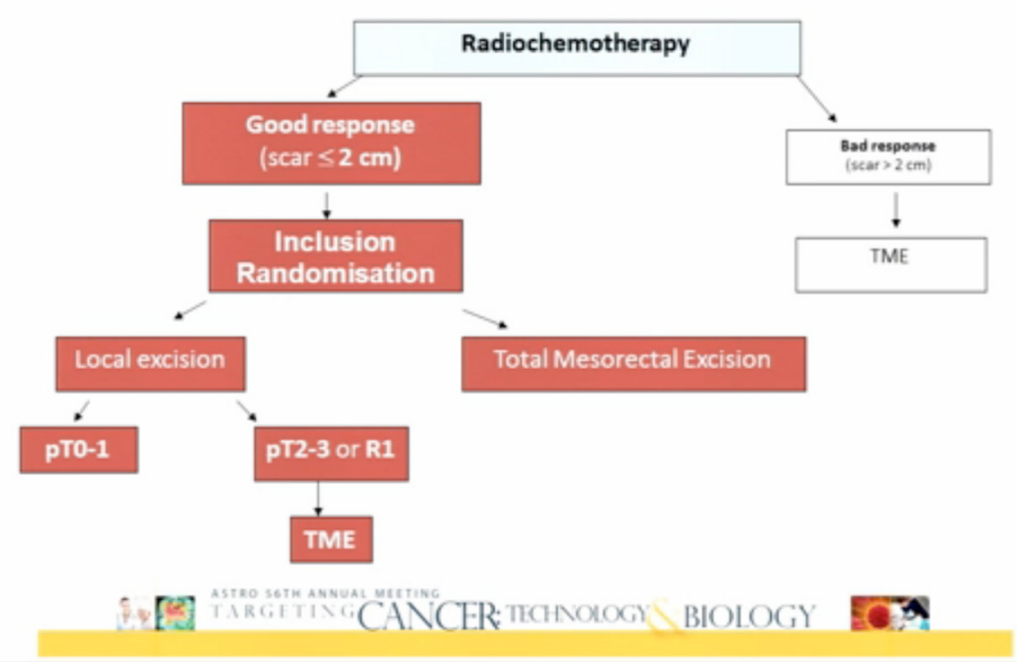

Rycina 1. Schemat badania GRECCAR II.

Źródło: konferencja ASTRO 56th - Virtual Meeting.

zakwalifikowanej do miejscowej resekcji, mniej niż u połowy wystąpiły cechy histopatologiczne wymagające konwersji do konwencjonalnego zabiegu TME.

Łącznie w obu grupach obserwowano 40\% całkowitą odpowiedź ze strony guza - jest to wynik wstępnej selekcji chorych. Autorzy podkreślili, że całkowite remisje, łącznie z guzami pT1 stanowiły razem 61\% przypadków, zatem oszczędzający zabieg można by potencjalnie przeprowadzić u prawie 2/3 chorych. Dane odnośnie odpowiedzi węzłowej pochodzą oczywiście tylko od pacjentów u których wycięto mezorectum. Akcentowano tutaj fakt, że jeśli odpowiedź ze strony guza była całkowita lub znaczna (pTo, pT1), to nie stwierdzano rezydualnych zajętych węzłów chłonnych. Wszyscy zatem chorzy, którzy mogliby mieć wykonaną miejscową resekcję, nie mieli zarazem przetrwałej choroby węzłowej.

Do tej pory proponowano miejscową resekcję jedynie wybranym chorym z guzem T1 [4]. W tym badaniu pokazano, że tę metodę można zaoferować również części pacjentom $\mathrm{z}$ głębiej naciekającym nowotworem (T2-3) lub zajętymi węzłami $\mathrm{z}$ dobrą odpowiedzią na radiochemioterapię, bez guz w stopniu cT2-3 musiał znajdować się $\mathrm{w}$ dolnych $2 / 3$ odbytnicy, mieć maksymalnie $4 \mathrm{~cm} \mathrm{i} \mathrm{-} \mathrm{co} \mathrm{ważne} \mathrm{-}$ dopuszczalna była cecha cN1, ale z węzłami maksymalnie 8-milimetrowymi. Oceny przed leczeniem dokonywano klinicznie iprzypomocybadań obrazowych: rezonans magnetyczny, tomografia komputerowa klatki piersiowej i jamy brzusznej oraz endoskopowe przezodbytnicze usg.

Radiochemioterapię przeprowadzono według obowiązującego schematu (50Gy+ kapecytabina) [2], początkowo stosowano również oksaliplatynę, z której zrezygnowano po niekorzystnych doniesieniach z badania ACCORD [3]). Po 6-8 tygodniach od zakończenia leczenia skojarzonego oceniano odpowiedź w taki sam sposób jak przy kwalifikacji do niego. U 3/4 pacjentów odpowiedź na takie leczenie była dobra - obserwowano guz resztkowy do $2 \mathrm{~cm}$. W grupie

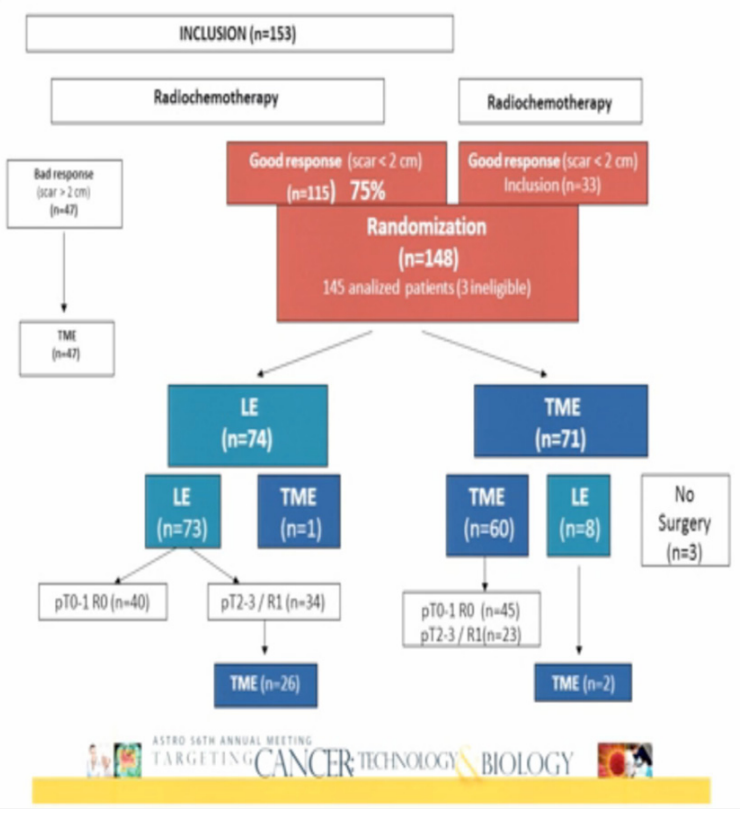

Rycina 2. Nabór do badania GRECCAR II. Źródło: konferencja ASTRO 56th - Virtual Meeting. 


\begin{tabular}{|c|c|c|c|c|}
\hline & $\begin{array}{c}\text { LE } \\
(\mathrm{n}=81)\end{array}$ & $\begin{array}{c}\text { TME } \\
(\mathrm{n}=61\end{array}$ & $\begin{array}{c}\text { wszystkie } \\
(\mathrm{n}=142)\end{array}$ & $\%$ \\
\hline pTo & 27 & 30 & 57 & 40 \\
\hline pT1 & 17 & 12 & 29 & 21 \\
\hline pT2 & 31 & 15 & 46 & 32 \\
\hline pT3 & 6 & 4 & 10 & 7 \\
\hline
\end{tabular}

Tabela 1. Wyniki odpowiedzi ze strony guza pierwotnego po leczeniu neoadjuwantowym według sposobu pierwotnego leczenia chirurgicznego (LE - miejscowe wycięcie, TME - całkowite wycięcie mezorektum). Źródło: opracowanie własne

\begin{tabular}{|c|c|c|c|c|}
\hline & $\begin{array}{c}\text { 1.TME } \\
(\mathrm{n}=61)\end{array}$ & $\begin{array}{c}2 . \mathrm{TME} \\
(\mathrm{n}=28\end{array}$ & $\begin{array}{c}\text { Wszystkie } \\
\text { TME } \\
(\mathrm{n}=89)\end{array}$ & $\%$ \\
\hline pTo & $0 / 30$ & 0 & $0 / 30$ & 0 \\
\hline pT1 & $0 / 12$ & $0 / 1$ & $0 / 13$ & 0 \\
\hline pT2 & $1 / 15$ & $2 / 21$ & $3 / 36$ & 8 \\
\hline pT3 & $2 / 4$ & $2 / 6$ & $4 / 10$ & 10 \\
\hline
\end{tabular}

Tabela 2. Liczba zajętych węzłów chłonnych (oraz liczba pacjentów) w zależności od cechy pT w grupie leczonej metodą TME pierwotnie i jako konwersja po metodzie LE. Źródło: opracowanie własne

ryzyka pozostawienia $\mathrm{u}$ nich dodatnich węzłów chłonnych. Jest to warte uwagi podejście w deeskalacji leczenia chirurgicznego.

Taki trójstopniowy schemat, jeśli zostałby zaakceptowany, z pewnością możliwy byłby do przeprowadzenia jedynie w niewielu wysokospecjalistycznych ośrodkach; obarczonym wysokimi kosztami.

Drugie prezentowane randomizowane badanie kliniczne III fazy jest autorstwa polskich badaczy z Instytutu Onkologii w Gliwicach pod kierownictwem dr Iwony Wziętek [5]. Porównali oni dwa schematy radioterapii przedoperacyjnej: hypo- i hyperfrakcjonowany (HYPO i HART). W obu znacznie skrócono czas leczenia w porównaniu z konwencjonalną radiochemioterapią - zamiast 5 tygodni wyniósł on 2.5 tygodnia.

\section{Trial design}

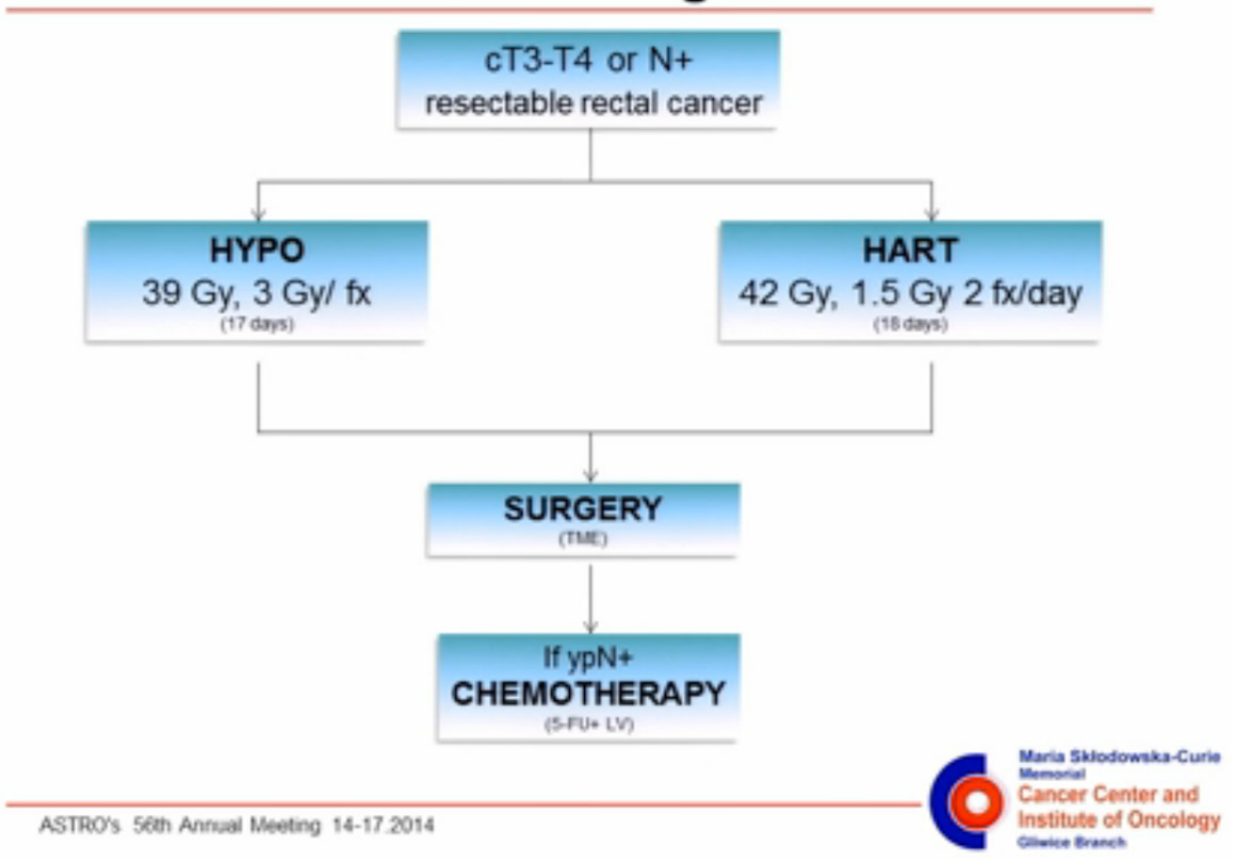

Rycina 3. Schemat badania randomizowanego „Hiperfrakcjonowana vs hypofrakcjonowana przedoperacyjna radioterapia w raku odbytnicy”. Źródło: konferencja ASTRO 56th - Virtual Meeting. 
Oba schematy były dobrze tolerowane, odczyn w 3-4 stopniu obserwowany był zaledwie u kilku chorych z obu ramion; obserwowano nieco częstszy ostry odczyn ze strony pęcherza moczowego w grupie HART. Zaobserwowano nieco więcej powikłań wymagających operacji w grupie HYPO (21 vs 13\%), ale łączny odsetek wszystkich powikłań okołooperacyjnych był zbliżony w obydwu grupach. Nie obserwowano jakichkolwiek różnic pod względem kontroli lokoregionalnej, przeżycia wolnego od przerzutów oraz przeżycia całkowitego. W zakresie wskaźników jakości życia widoczne były istotne różnice na korzyść hiperfrakcjonacji: pacjenci z tej grupy 3-5 lat po leczeniu mieli mniej objawów somatycznych: dysurii, problemów ze stomią oraz bezsenności i - prawdopodobnie w następstwie tego - funkcjonowali lepiej w życiu codziennym. Zauważalny ochronny efekt względem późnych odczynów popromiennych wynikał z podania mniejszych dawek frakcyjnych. Autorzy słusznie spodziewali się braku różnic w zakresie wyników odległych - nie mogło ich być przy podobnym w obu grupach czasie leczenia i dawce znormalizowanej [6]. Żaden z zaprezentowanych schematów nie jest jednak standardem, trudno je odnieść do powszechnie stosowanych schematów 5x5Gy lub 28x1.8Gy [4].
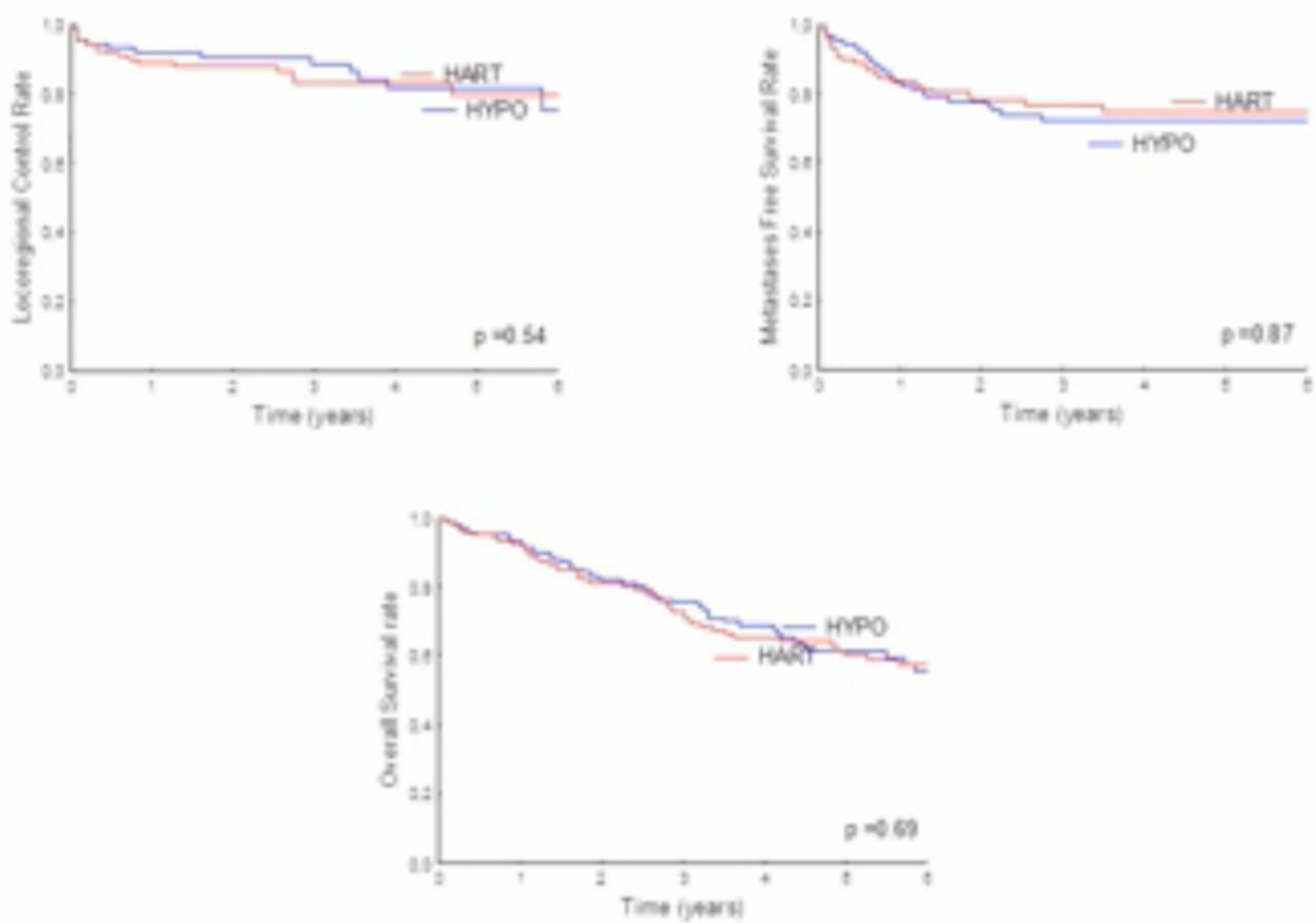

ASTROO's 5th Anrual Weeting 14-17 2014

Rycina 4. Kolejno: kontrola loko regionalna, przeżycie wolne od przerzutów i przeżycie całkowite w podgrupach HART i HYPO. Źródło: konferencja ASTRO 56th - Virtual Meeting.

Europejski projekt wieloośrodkowy z udziałem ośrodków z Belgii, Francji, Włoch, Litwy - to kolejne badanie trzeciej fazy w prezentowanej tematyce [7]. Porównano w nim konwencjonalną radiochemioterapię przedoperacyjną z samodzielną radioterapią z równoczasowym zintegrowanym boostem (SIB). Stosowano podwyższoną dawkę frakcyjną na guz, w każdej frakcji wyniosła ona 2.4 Gy, łącznie otrzymywał on dawkę o 10 Gy wyższą niż standardowe 50 Gy. Kwalifikowano pacjentów cT3-4, przeważnie (85\%) N+.

Ze względów statystycznych wybrano dość kontrowersyjny punkt końcowy: odpowiedź metaboliczna mierzona w badaniu PET-CT 5 tygodni od zakończenia leczenia indukcyjnego (wymagało to mniej licznej grupy chorych). Było to badanie typu non-inferiority i założono że spełnienie tego warunku zajdzie, gdy 
różnicach w spadkach wartości SUV między ramionami wyniosą poniżej 10\%.

Zastosowanie radioterapii IMRT kierowanej obrazem skutkowało niewielką toksycznością 3. stopnia. Wyniki obserwacji odnośnie odczynów późnych są na razie zbyt wczesne, bowiem mediana obserwacji wynosi zaledwie 14 miesięcy.

Obserwowano podobny odsetek odpowiedzi patologicznych w grupie, różnice tutaj nie były statystycznie istotne. Różnic w komplikacjach okołooperacyjnych nie było. Odpowiedzi metaboliczne były zbliżone w obu grupach - warunek non-inferiority został spełniony.

Nie jest więc zaskoczeniem brak różnic w pozostałych punktach końcowych: przeżyciach calkowitych, wolnych od progresji i kontroli miejscowej.

\begin{tabular}{|c|c|c|c|c|}
\hline & \multicolumn{2}{|c|}{ RTChT (n=59) } & \multicolumn{2}{c|}{ SIB (n=55) } \\
stopień & 2 & 3 & 2 & 3 \\
\hline Enteritis & $36 \%$ & $0 \%$ & $25 \%$ & $0 \%$ \\
\hline Proctitis & $19 \%$ & $0 \%$ & $24 \%$ & $2 \%$ \\
\hline Dysuria & $8 \%$ & $0 \%$ & $13 \%$ & $0 \%$ \\
\hline Rumień & $14 \%$ & $3 \%$ & $15 \%$ & $2 \%$ \\
\hline Mucositis & $2 \%$ & $2 \%$ & $0 \%$ & $0 \%$ \\
\hline $\begin{array}{c}\text { Toksyczność } \\
\text { hematologiczna }\end{array}$ & $5 \%$ & $5 \%$ & $0 \%$ & $0 \%$ \\
\hline
\end{tabular}

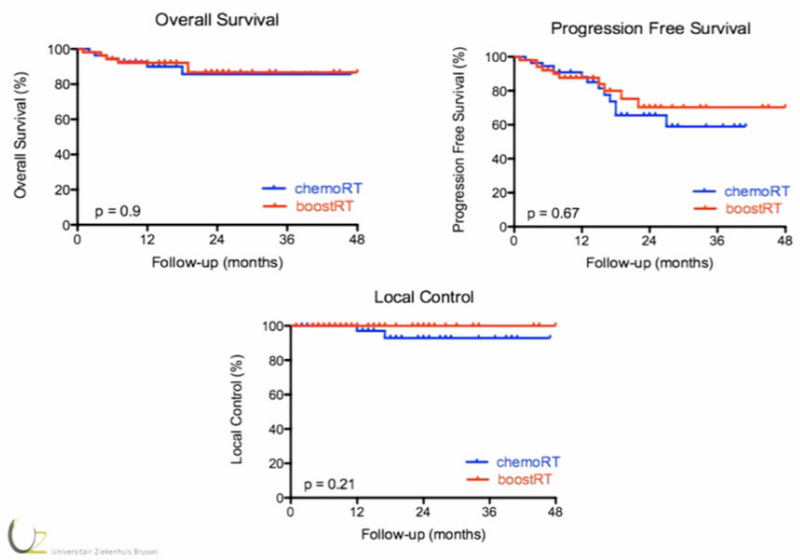

Tabela 3. Toksyczność wczesna w stopniu 2. i 3. wg skali CTCAE 4.0 w grupach badania „Porównanie przedoperacyjnej radioterapii-SIB z radiochemioterapią $\mathrm{w}$ raku odbytnicy".

Źródło: opracowanie własne.

Rycina 5. Kolejno: przeżycia całkowite, przeżycia wolne od progresji, kontrola miejscowa w grupach badania „Porównanie przedoperacyjnej radioterapiiSIB z radiochemioterapią w raku odbytnicy".

Źródło: konferencja ASTRO 56th - Virtual Meeting.

Autorzy uznali, że samodzielna radioterapia z SIB może być alternatywą leczenia dla chorych nie kwalifikujących się do chemioterapii lub nie wyrażających na nią zgody. W krytyce wymieniano, że odpowiedź metaboliczna nie jest silnym punktem końcowym, jedynie surogatem odpowiedzi na leczenie. Część komentujących uważała, że nie jest to właściwy kierunek w postępowaniu. Eliminuje on lub oddala adjuwantową chemioterapię w czasie - a ta ma działanie ponadregionalne, wpływa bowiem na przeżycia całkowite [13].

Pojawiło się jedno doniesienie o nowym leku, potencjalnie użytecznym w leczeniu skojarzonym - jest nim velaparib - inhibitor poli-ADP-rybozo-polimerazy (PARP) [8]. Ta grupa enzymów rozpoznaje uszkodzenia DNA, szczególnie pojedynczoniciowe pęknięcia i warunkujących ich dalszą naprawę. Udowodniono in-vitro radio- i chemiouczulający efekt inhibitorów PARP. Preparat testowany był w badaniu I fazy. Uznano velaparib za bezpieczny i atrakcyjny związek do testowania z radioterapią - umożliwia bowiem potencjalnie zupełnie nowy sposób radiosensytyzacji.

Pojawiają się wciąż wyniki badań oceniających efekty dodania oksaliplatyny do standardowej radiochemioterapii - podejście takie nie poprawia wyników leczenia a znacznie zwiększa jego toksyczność [9].

Tematyka wystąpień dotyczących raka odbytu skupiała się na ograniczaniu toksyczności leczenia skojarzonego, wiele uwagi poświęcono również na roli infekcji HPV i jej znaczenia w prognozie.

Niepożądane zdarzenia hematologiczne to główna grupa poważnych powikłań wczesnych w trakcie leczenia skojarzonego raka kanału odbytu [10]. Obserwuje się przeważnie neutropenię z leukopenią. Wynika to głównie z mielotoksycznego działania mitomycyny, w mniejszym stopniu fluorouracylu, ale jest to również rezultat napromieniania znacznych objętości tkanek w obrębie miednicy i zarazem jam szpikowych. W związku z tym zdefiniowanie dawek tolerancji na szpik znajdujący się w kościach miednicy może przyczynić się do zmniejszenia toksyczności hematologicznej w leczeniu skojarzonym raka odbytu, gdyż połowa szpiku 
kostnego u osób dorosłych znajduje się właśnie tam.

Autorzy jednej z prezentacji definiowali najbardziej optymalne dawki tolerancji szpiku kostnego a także identyfikowali lokalizacje szpiku która może mieć największe znaczenie kliniczne w rozwoju powikłań [11]. Przeprowadzono retrospektywną analizę dozymetryczną u 56 pacjentów leczonych na University of Chicago. Zestawiono ją z obserwowanymi powikłaniami a następnie dokonano prospektywnej walidacji otrzymanych dawek tolerancji.

Toksyczność hematologiczna w największym stopniu wynikła z dawki promieniowania podanej na dolną cześć miednicy; również parametr V40 był istotny tylko w tej części szpiku. Jest to zrozumiałe - dolna część miednicy zawiera objętościowo najwięcej szpiku, jest on tam najbardziej aktywny, tej części dotyczą też pola boostowe.

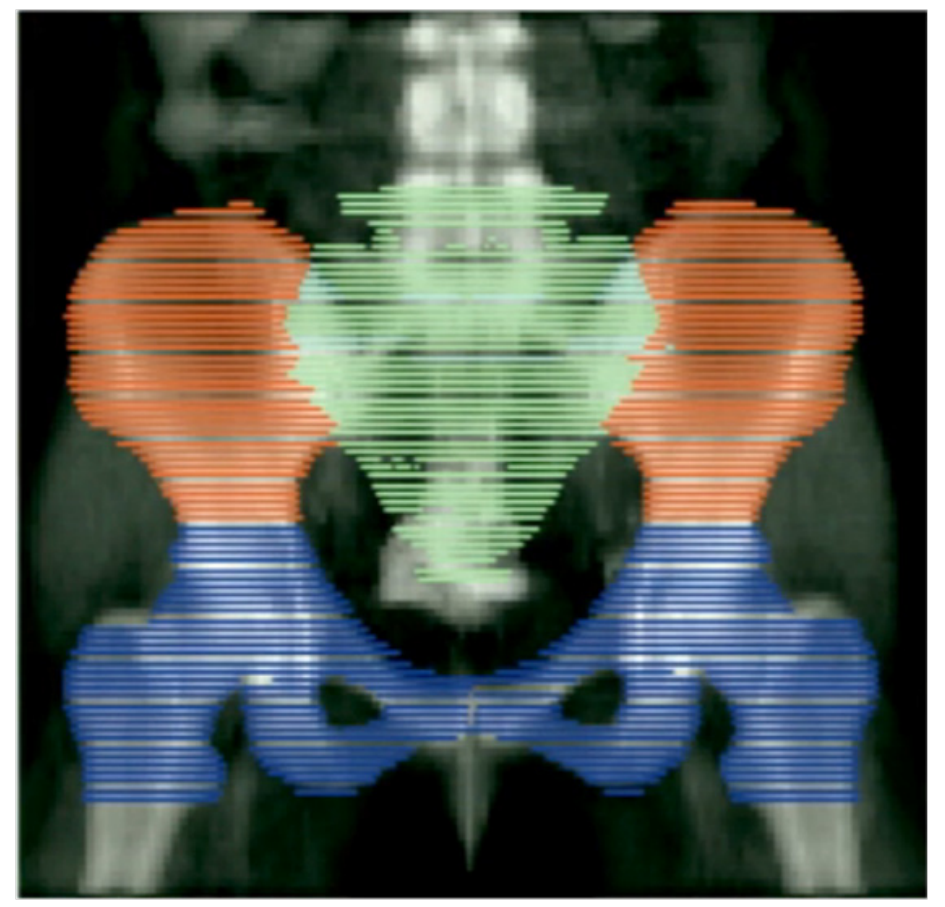

Rycina 6. Przykład konturowania jam szpikowych. Kolor zielony - kość krzyżowa i dolny odcinek kręgosłupa lędźwiowego, kolor czerwony - górna część miednicy, kolor niebieski - dolna część miednicy.

Źródło: konferencja ASTRO 56th - Virtual Meeting.

Stąd autorzy zidentyfikowali parametry: V20<90\% i V40<25\% na dolną część miednicy jako najbardziej użyteczne objętościowe dawki tolerancji - ich łączne spełnienie skutkowało istotnym obniżeniem odsetka ciężkiej leuko- i neutropenii ocenionej w próbie prospektywnej. Efekt taki obserwowano tylko u osób $\mathrm{z}$ prawidłową masą ciała $(\mathrm{BMI}<25)$.

Ten związek raportowano już w innych publikacjach i to nie tylko w raku odbytu. Przypuszczalnie jest to związane ze względnym niedodawkowaniem cytostatyków u osób otyłych lub też ich farmakokinetyką i farmakodynamiką.

Karyn Goodman wraz z zespołem skupiła się na analizie prospektywnej skuteczności leczenia i działań niepożądanych w trakcie zmodyfikowanej radiochemioterapii u pacjentów z rakiem odbytu. Modyfikacja polega na zastąpieniu fluorouracylu kapecytabiną (Xeloda) [12]. Ten preparat w postaci doustnej jest prekursorem 5-fluorouracylu, przekształcający się do aktywnego cytostatyku pod wpływem fosforylazy tymidynowej, której aktywność w komórkach nowotworowych jest zwiększona. Ma to zapewnić wyższe stężenie leku w tkance guza, obniżenie częstości działań niepożądanych oraz uniknięcie niewygodnego ciągłego wlewu dożylnego 5-Fu. Liczne badania w nowotworach przewodu pokarmowego o innej lokalizacji zademonstrowały, że kapecytabina jest przynajmniej równoważnikiem 5-fluorouracylu [13].

Analiza toksyczności ujawniła znaczną redukcję odsetka ciężkich zaburzeń hematologicznych - neutropenii i leukopenii w grupie z Xelodą. Przełożyło się to znacznie rzadsze przerwy w leczeniu u tych chorych i krótszy 


\begin{tabular}{|c|c|c|c|}
\hline & $\begin{array}{c}5 \text {-FU+ } \\
\text { MMC } \\
(\mathrm{n}=64)\end{array}$ & $\begin{array}{c}\text { Cape+ } \\
\text { MMC } \\
(\mathrm{n}=44)\end{array}$ & $\mathrm{p}$ \\
\hline $\mathrm{G} 3+$ neutropenia & $50 \%$ & $9 \%$ & $<0.0001$ \\
\hline G3+ leukopenia & $52 \%$ & $25 \%$ & 0.009 \\
\hline G3+ trombocytopenia & $16 \%$ & $5 \%$ & 0.12 \\
\hline G3+ niedokrwistość & $8 \%$ & $2 \%$ & 0.40 \\
\hline Redukcja dawki ChT & $52 \%$ & $16 \%$ & \\
\hline Przerwy w leczeniu & $41 \%$ & $16 \%$ & 0.006 \\
\hline Czas leczenia & 40 & 37 & 0.002 \\
\hline
\end{tabular}

Tabela 4. Toksyczność ostra oraz parametry związane z leczeniem w grupach badania „Kapecytabina z mitomycyną w radiochemioterapii raka płaskonabłonkowego kanału odbytu”.

Źródło: opracowanie własne

czas jego trwania. Również potrzeba zredukowania dawki cytostatyków pojawiła się tutaj jedynie u co 6 . pacjenta, względem co 2. w grupie porównawczej.

Ocena wyników odległych nie była pierwszorzędowym celem badania, autorzy pokazali, że - dla tego dość krótkiego okresu obserwacji (mediana 15 miesięcy) - nie występuje jakikolwiek negatywny wpływ zamiany cytostatyków na odsetek przeżyć całkowitych, niepowodzenia miejscowe i odległe. Praca ta stała się podstawą umieszczenia w aktualnych rekomendacjach kapecytabiny jako alternatywy dla 5-fluorouracylu w radiochemioterapii raka odbytu, mimo że brak wciąż prospektywnej oceny skuteczności kapecytabiny w leczeniu skojarzonym raka odbytu.

W trzech ustnych prezentacjach skupiono się na wirusie brodawczaka ludzkiego (HPV) jako ważnym biomarkerze raka odbytu. Infekcję HPV, ocenianej poprzez ekspresję białka p16 obserwuje się u około 85\% chorych z rakiem odbytu [10].

W retrospektywnej analizie przeprowadzonej przez niemiecki zespół profesora Mai wiązano wpływ statusu infekcji HPV na rokowanie u chorych leczonych w sposób skojarzony [14]. Status HPV był określany na dwa sposoby: poprzez ocenę ekspresji wirusowego białka p16 oraz poszukiwanie DNA wirusa. Obserwowano wszelkie możliwe kombinację obecności obydwu biomarkerów.

\begin{tabular}{|c|c|c|}
\hline & p16+ & p16- \\
\hline HPV+ & Group 1 & Group 2 \\
& $63(59 \%)$ & $9(9 \%)$ \\
\hline HPV- & Group 3 & Group 4 \\
& $11(10 \%)$ & $23(22 \%)$ \\
\hline
\end{tabular}

Rycina 7. Status HPV u pacjentów z rakiem odbytu w zależności od obecności HPV-DNA i białka p-16 i wyodrębnienie na tej podstawie 4 grup chorych.

Źródło: konferencja ASTRO 56th - Virtual Meeting. 


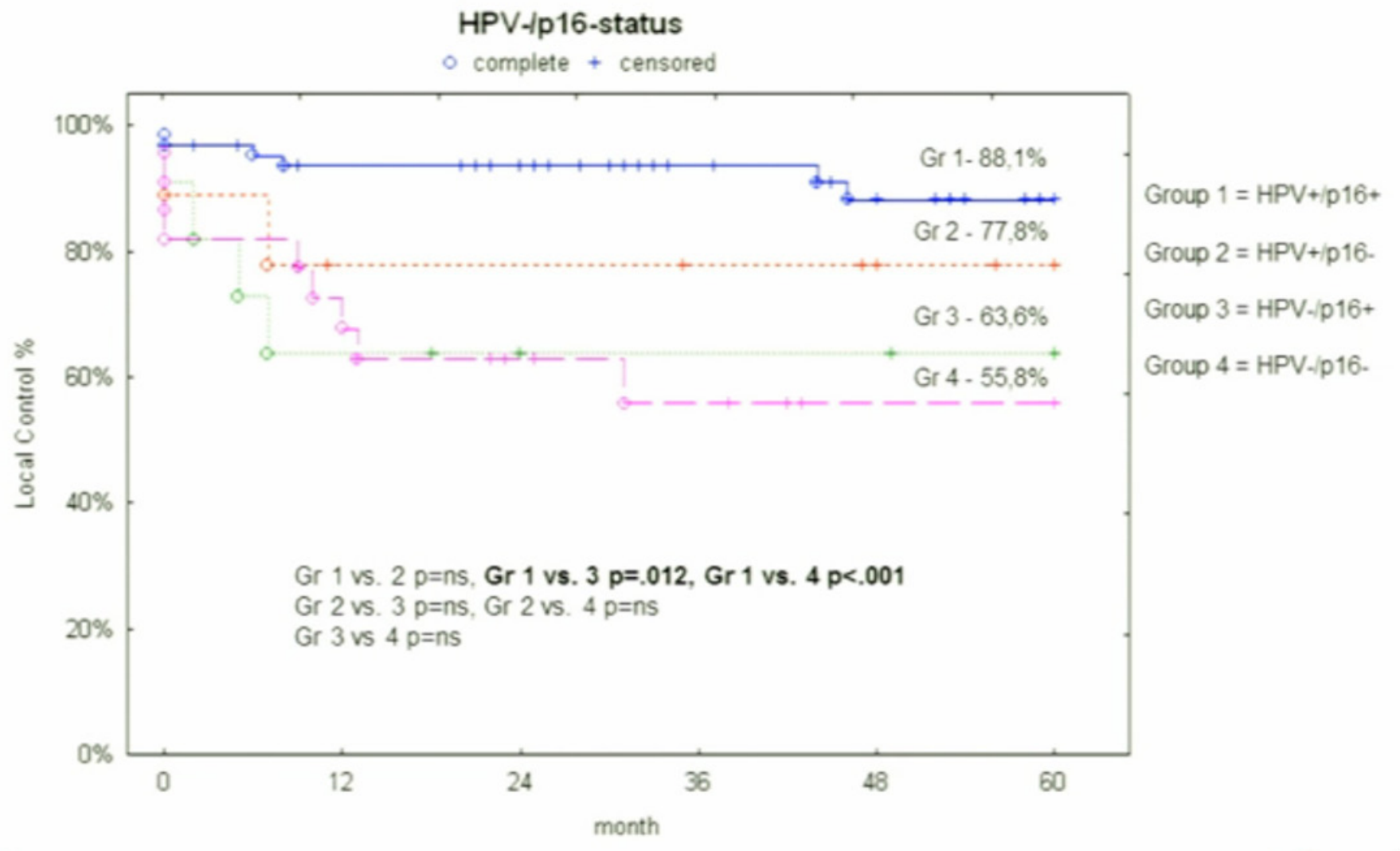

Rycina 8. Kontrola miejscowa u chorych z rakiem odbytu w zależności od statusu HPV (na podstawie podziału wg ryciny 7.). Źródło: konferencja ASTRO 56th - Virtual Meeting.

Podkreślono, że pacjenci HPV+/p16+ są skutecznie leczeni z zastosowaniem obecnie stosowanych dawek promieniowania i cytostatyków (najlepsza prognoza, grupa 1. wg ryciny 8.), natomiast chorzy HPV-/p16- mają najgorszą prognozę i mogą wymagać intensyfikacji leczenia. Ustalono też jednoznacznie, że nadekspresja białka p16 jest korzystnym czynnikiem rokowniczym tylko wówczas, gdy jest ona wynikiem infekcji HPV.

Status HPV powinien być nowym ważnym czynnikiem stratyfikacyjnym w badaniach klinicznych; jest wcześnie osiągalnym prognostycznym biomarkerem. Możliwe że choroba wymaga odrębnego stagingu podobnie jak rak gardła środkowego - i, być może, różnicowania strategii leczniczych. Obecnie brakuje wciąż jednolitych kryteriów uznania nowotworu za HPV dodatni. Brak też zgody, który biomarker i na jakim poziomie powinien służyć za kryterium.

\section{Konflikt interesu / Conflict of interest}

Nie występuje / None

\section{Etyka / Ethics}

Treści przedstawione w artykule są zgodne z zasadami Deklaracji Helsińskiej, dyrektywami EU oraz ujednoliconymi wymaganiami dla czasopism biomedycznych. 


\section{Piśmiennictwo / References}

[1] Vendrely V, Rullier E, Rouanet P, Tuech JJ, Mosnier H et al. Local Excision Versus Total Mesorectal Excision in Patients with Good Response After Neoadjuvant Radiochemotherapy for T2-T3 Low Rectal Cancer: Preliminary Results of the GRECCAR 2 Randomized Phase 3 Trial. Int J Radiat Oncol Biol Phys. Sept 2014; Vol 90, Issue 1, Supplement, S20.

[2] Rekomendacje diagnostyki i leczenia nowotworów złośliwych wg American Society for Radiation Oncology: https://www.astro.org/clinical-practice/guidelines/index.aspx

[3] Gérard JP, Azria D, Gourgou-Bourgade S, Martel-Lafay I, Hennequin C et al. Clinical outcome of the ACCORD 12/0405 PRODIGE 2 randomized trial in rectal cancer. Journal of Clinical Oncology. 2012 Dec 20; 30(36):4558-65.

[4] Krzakowski M (red.). Zalecenia postępowania diagnostyczno-terapeutycznego w nowotworach złośliwych - 2013r. Via Medica, Gdańsk 2013.

[5] Wzietek I, Kryj M, Idasiak A, Bialas M, Chmielarz A et al. Randomized Clinical Trial on Hyperfractionated Versus Hypofractionated Preoperative Radiotherapy for Rectal Cancer: Long Term Outcomes Including Quality of Life Assessment. Int J Radiat Oncol Biol Phys. Sept 2014; Vol 90, Issue 1, Supplement, S37.

[6] Van der Kogel A, Joiner M. Basic Clinical Radiobiology. 4th Edition.

[7] Engels B, De Paoli A, Cattari G, Munoz F, Vagge S Preoperative Radiotherapy with a Simultaneous Integrated Boost Compared to Chemoradiation therapy for T3-4 Rectal Cancer: Interim Analysis of a Multicentric Randomized Trial. Int J Radiat Oncol Biol Phys. Sept 2014; Vol 90, Issue 1, Supplement, S22-23.

[8] Czito B, Mulcahy M, Schelman W, Vaghefi H, Gayle Jet al. The Safety and Tolerability of Veliparib plus Capecitabine and Radiation in Subjects with Locally Advanced Rectal Cancer: Results of a Phase $1 \mathrm{~b}$ Study. Int J Radiat Oncol Biol Phys. Sept 2014; Vol 90, Issue 1, Supplement, S22.

[9] Hong TS, Moughan J, Garofalo M, Bendell J, Berger AC et al. Efficacy Outcomes from RTOG o822: A Phase II Study of Neoadjuvant IMRT with Capecitabine and Oxaliplatin in Patients with Locally Advanced Rectal Cancer. Int J Radiat Oncol Biol Phys. Sept 2014; Vol 90, Issue 1, Supplement, S21.

[10] Cummings BJ, Brierley JD Anal Cancer w: Halperin EC, Wazer D, Perez CA, Brady LW Principles and Practice of Radiation Oncology. Sixth Edition. Wolters Kluwer, Lippincott Williams \& Wilkins, Philadelphia, 2013.

[11] Lee AY, Bazan JG, Pelizzari CA, Chang DT, Liauw SL Lower Pelvis Bone Marrow Dose Constraints to Reduce Hematologic Toxicity in the Treatment of Anal Cancer. Int J Radiat Oncol Biol Phys. Sept 2014; Vol 90, Issue 1, Supplement, S33.

[12] Goodman KA, Rothenstein D, Lajhem C, Wu A, Cercek A Capecitabine Plus Mitomycin in Patients Undergoing Definitive Chemoradiation for Anal Squamous Cell Carcinoma. Int J Radiat Oncol Biol Phys. Sept 2014; Vol 90, Issue 1, Supplement, S32.

[13] Jeziorski KG, Potemski P. Systemowe leczenie zaawansowanych nowotworów układu pokarmowego w: Jassem J., Krzakowski M. (red.) Nowotwory układu pokarmowego. Via Medica, Gdańsk 2014.

[14] Mai SK, Reuschenbach M, Ottstadt M, Welzel G, Severa S. The Influence of HPV-Status on Outcome of Anal Cancer Treated with Radio-Chemotherapy. Int J Radiat Oncol Biol Phys. Sept 2014; Vol 90, Issue 1, Supplement, S31-32. 